$U D C 78.072 .2$

DOI $10.33287 / 222010$

Varakuta Maryna, PhD in Arts, the Associate Professor of the „History and Theory of Music" chair, Dnipropetrovsk Music Academy after Mikhail Glinka тел. (097) 998 - 78 - 99 e-mail: amilomarina@i.ua

Dashko Vladimir, Graduate student of the chair ,Vocal-choral mastery” of Dnipropetrovsk Music Academy after Mikhail Glinka тел. (093) 284 - 65 - 58 e-mail: vladimirdashco@gmail.com

\title{
TO THE PROBLEM \\ OF THE MAGNIFICAT GENRE READING IN CREATIVE WORK OF JOHN RUTTER
}

The purpose of this article is to uncover some features of realization of the Magnificat genre in the creative work of John Milford Ratter, contemporary world famous composer, conductor, arranger, notes publisher, which received wide recognition, in the first place, as the author of numerous artistic compositions into the sphere of academically professional choral art. The round of scientifically investigative methods relies on a genre-based approach, stylistic and functional approaches of the research analysis. The explorers are also having the process of applying the structurally analytical as well as comparative methods, specialized ways for studying of the abovementioned problem. The scientific novelty of the article is in the illumination of compositional features, timbre-texture decisions in the Magnificat genre in creative work of John Ratter that until now did not appear in modern domestic musicology research. The authors of represented article are investigating, for the first time, in the Ukrainian musicological thought, the problem concerning succession and regeneration of leading, the most crucial genre indications of Magnificat in compositionally artistic observation by John Milford Ratter. 
Conclusions. The Magnificat of John Rutter illustrates a new way of reading of this genre by the prime example of an unconventional embodiment of the classic genre model based on the synthesis of canonical and not canonical texts. The choral work attracts by its openness, sincerity, lyric artistic images that can be easily remembered, its melodious and harmonious colours, simplicity for understanding. The composer harmoniously combines traditions and their talented renewal: in this sense, the Magnificat is a model for the musical culture of the second half of the XX century and the beginning of the XXI century.

The key words: genres of choral music, the Magnificat genre, English choral music.

Варакута Марина Іванівна, кандидат мистецтвознавства, доцент, доцент кафедри „Історія та теорія музики” Дніпропетровської академії музики ім. М. Глінки

Дашко Володимир Миколайович, магістрант кафедри „Вокально-хорова майстерність” Дніпропетровської академії музики ім. М. Глінки

До проблеми прочитання жанру Магніфікат у творчості Джона Раттера

Метою статті $\epsilon$ виявлення деяких особливостей втілення жанру магніфікату в творчості Джона Мілфорда Раттера, сучасного всесвітньо відомого Великобританського композитора, диригента, аранжувальника, нотного видавця, який отримав визнання, насамперед, як автор численних композицій у сфері академічного хорового мистецтва. Коло методів пропонованого наукового дослідження базується на історико-типологічному, жанровому, стильовому й функціональному методах аналізу. Науковці також вдаються до застосування структурно-аналітичного та порівняльного методів вивчення вищеозначеної проблеми. Наукова новизна статті полягає у висвітленні композиційних особливостей, темброво-фактурних рішень жанру магніфікату Джона Раттера, що досі не ставало предметом грунтовного дослідження в сучасному вітчизняному музикознавстві. Автори зазначеної статті вперше досліджують в українській музикознавчій думці проблему спадкоємності та регенерації провідних, найбільш ключових жанрових показників магніфікату в композиційнохудожньому баченні Джона Раттера. Висновки. Магніфікат Джона Мілфорда Раттера є абсолютно новим прочитанням цього жанру, 
самобутньо-характерним, яскравим прикладом новітнього, нетрадиційного втілення класичної жанрової моделі на основі синтезу канонічного, а також неканонічного текстів. Акцентований у пропонованому дослідженні хоровий твір приваблює своєю відкритістю, щирістю, ліричністю образів, що запам'ятовуються мелодійними та гармонійними фарбами, особливою доступністю художньо-образного, ідейно-змістовного сприйняття. Композитор гармонійно поєднує в музичному творі слідування встановленим традиціям, а також їх талановите оновлення. Саме у цьому сенсі жанр Магніфікату $є$ показовим для сучасної академічної європейської музичної культури періоду другої половини ХX початку XXI століть.

Ключові слова: хорові жанри, жанр „Магніфікат”, англійська хорова музика.

Варакута Марина Ивановна, кандидат искусствоведения, доцент, доцент кафедры „История и теория музыки” Днепропетровской академии музыки им. М. Глинки

Дашко Владимир Николаевич, магистрант кафедры „Вокально-хоровое мастерство” Днепропетровской академии музыки им. М. Глинки

\section{К проблеме прочтения жанра Магнификат в творчестве Джона Раттера}

Целью статьи является выявление некоторых особенностей воплощения жанра магнификата в творчестве Джона Милфорда Раттера, современного всемирно известного композитора, дирижера, аранжировщика, нотного издателя, который получил признание, прежде всего, как автор многочисленных композиций в сфере академического хорового искусства. Перечень методов предлагаемого научного исследования базируется на историкотипологическом, жанровом, стилевом и функциональном методах анализа. Ученые также используют структурно-аналитический и сравнительный методы изучения вышеотмеченной проблемы. Научная новизна статьи заключается в освещении композиционных особенностей, темброво-фактурных решений жанра магнификата у Дж. Раттера, что до сих пор не становилось предметом исследования в современном отечественном музыковедении. Авторы представленной статьи впервые исследуют в украинской музыковедческой мысли проблему наследственности 
и регенерации ведущих, наиболее ключевых жанровых показателей магнификата в композиционно-художественном видении Джона Раттера. Выводы. Магнификат Джона Милфорда Раттера является абсолютно новым прочтением этого жанра, самобытнохарактерным, ярким примером нового, нетрадиционного воплощения классической жанровой модели на основе синтеза канонического, а также неканонического текстов. Акцентированное в предложенном исследовании хоровое произведение привлекает своей открытостью, искренностью лирических образов, которые запоминаются мелодическими и гармоническими красками, особенной доступностью художественно-образного, идейносодержательного восприятия. Композитор гармонично сочетает в музыкальном произведении следование установленным традициям и их талантливое обновление. Именно в этом смысле Магнификат является показательным для современной академической европейской музыкальной культуры периода второй половины XX - начала XXI веков.

Ключевые слова: хоровые жанры, жанр „Магнификат”, английская хоровая музыка.

The statement of this problem. It becomes apparent, that the $\mathrm{XX}$ century has brought about its own amendments with regard to the dateless genre. It is not by chance that many composers approached the sacred themes because it is in the XX century that the special treatment of sacred culture, its revival and reinterpretation resulted from intensive renewal of means of musical expression and context, as well as, the field of the genre. Those conditions the topicality of the research dedicated to the Magnificat genre.

Analysis of the recent research and publications. There are few papers dedicated to works of J. Rutter, which is especially the case with respect to the domestic musicology. Yu. S. Kuchurivskyi explores the Requiem genre along with the choral music of British composers [3]; individual papers are dedicated to the sacred works by J. Rutter $[4 ; 5 ; 6]$. Video recordings of the Magnificat and other works by the composer were used as means for discovery of the particularities of his choral style writing in general.

The purpose of this article is to revealing some of the specifics of the Magnificat genre reading in bright, creative works, masterpeaces by J. Rutter. 
The object of the study is historically determined body of characteristics of the Magnificat genre; subject of this research is the scope of specifics concerning the Magnificat genre in J. Rutter's creative works.

The results and discussion. The fate of the Magnificat genre in the history of XX century music is unique. It is well known that the Magnificat is the song of thanks „My soul doth magnify the Lord” sung by Mary upon her relation's, St. Elizabeth's, who thus accepted Mary at her house as the Mother of God, blessing. The text is taken from the first chapter of the Gospel of Luke (1: 46-55). The Magnificat plays an important role in the worship of all religious traditions: for the Orthodox - in the Divine Office of Lauds; for Catholics the Latin version of the Magnificat is part of the Vespers.

A number of composers have addressed the texts of the Magnificat (J.S. Bach, K. Monteverdi, A. Vivaldi, as well as, modern composers A. Part, J. Rutter). The text of this canticle was recorded on the outer wall of the Church of the Visitation in Ein Karem in more than 50 languages. Being a part of the Protestant culture, the Magnificat genre has evolved significantly throughout its history. The interest in the Magnificat genre has been dynamically increasing, but its "Golden Age” took place in the XVII century. During the XIX century, the preoccupation with the genre fades away and is renewed in the $\mathrm{XX}$ century due to the mainstreaming of sacred topics. With regard to the choice of the language for the text, the new tendencies are emerging.

However, in the XVI century the Magnificats written in Latin were predominant. Influenced by the common tendencies of writing for different casts, the Magnificats were written in genres of vocal, vocalinstrumental of organ music. Most of the settings call for the undivided single choir a'cappella performance, while others require the division of the choirs. The larger scope of Magnificats is composed for a single choir. Magnificats that require two choirs are influenced by German's favourite of „,cori spezatti” and can be either accompanied by musical instruments or not.

The Magnificat, either in Latin or in German translation, has become a part of the Protestant Liturgy. Latin or German carols were included as interludes in the Magnificat that was part of the Protestant Liturgy tradition; traces of this tradition can be heard in J.S. Bach's Magnificat. Orlando di Lasso gave rise to a contratextural type of 
Magnificat. Later on, both sacred and secular music could have been used as a polyphonic primary source.

The deep spiritual essence of J. Rutter's works has drawn to his music a broad audience making composer's pieces popular all over the World. Nowadays, J. Rutter is not only a famous composer and conductor, but also University lecturer, as well as, an active participant of Music festivals and conferences hosted in Europe, Scandinavia, and Northern America.

J. Rutter's music is eclectic, it bears traces of French and English choral traditions of the XX century, along with, those of „light” music, classical American songs and Jazz traditions.

J. Rutter's Magnificat was written in 1985 for soprano solo, mixed chorus, and chamber orchestra; it is one of the brilliant examples of the genre interpretation. The piece synthesises stylistic features of different periods: mediaeval airs and modern traditions. It is an indicative piece for the music culture of letter half of the XX - the beginning of the XXI century. The piece is in seven movements:

1. Magnificat anima mea (My soul doth magnify the Lord).

2. Of a Rose, a lovely Rose.

3. Quia fecit mihi magna (For he that is mighty hath magnified me).

4. Et misericordia (And his mercy is on them that fear him: throughout all generations).

5. Fecit potentiam (He hath shewed strength).

6. Esurientes (He hath filled the hungry).

7. Gloria Patri (Glory be to the Father).

The character of the piece combines two emotional dimensions: repentance and bragging with I-III-V-VII movements being fast, trumpet-like, and brilliant, whereas movements II-IV-VI are lyrical, featuring soprano solo.

The opening theme (G-dur) of the first movement, „Magnificat anima mea" is light and brisk. Unlike Bach, who sets first verses in separate movements, J. Rutter combines first three verses into a single choral movement, creating various motifs and repeating the first verse at the end.

The second movement, „Of a Rose, a lovely rose”, deserves special attention. It is based on the text of English poem "Of a Rose, a Lovely Rose" that dates back to XV century. Its anonymous poet depicts Jesus as a rose, Mary as a rose bush with five branches: The 
Annunciation, a star over Bethlehem, three kings, the diminishing of the Devil's might, and Heavens. This highly lyrical movement evokes the style of medieval singing. The eight stanzas with three rhymes within its four lines are set to music as variations on the ostinato melody with addition of a concluding prayer „Pray we to her”.

\begin{tabular}{|c|c|c|c|c|c|c|c|}
\hline Opening & $\mathrm{A} 1$ & $\mathrm{~A} 2$ & $\mathrm{~A} 3$ & A4 & A5 & A6 & A7 \\
\hline & $\begin{array}{l}\text { "... this } \\
\text { rose } \\
\text { began to } \\
\text { spring } \\
. . . "\end{array}$ & $\begin{array}{l}\text { "... out of } \\
\text { her } \\
\text { bosom } \\
\text {..." }\end{array}$ & $\begin{array}{l}\text { "... an } \\
\text { angel } \\
\text { from } \\
\text { heaven's } \\
\text { tower } \\
\ldots "\end{array}$ & $\begin{array}{l}\text { "... a star } \\
\text { shone over } \\
\text { Bethlehem } \\
\ldots .\end{array}$ & $\begin{array}{l}\ldots \\
\text { three } \\
\text { kings } \\
\ldots "\end{array}$ & $\begin{array}{l}\text { "... sprang to } \\
\text { hell ..." }\end{array}$ & $\begin{array}{l}\text { "... sprang to } \\
\text { heaven ..." }\end{array}$ \\
\hline $\begin{array}{l}\text { Soprano, } \\
\text { alto, tenor }\end{array}$ & Bass & Alto & $\begin{array}{l}\text { Two } \\
\text { sopranos } \\
\text { and alto }\end{array}$ & $\begin{array}{l}\text { Tenor and } \\
\text { bass }\end{array}$ & Bass & $\begin{array}{l}\text { Soprano, } \\
\text { alto, tenor, } \\
\text { bass }\end{array}$ & $\begin{array}{l}\text { Soprano and } \\
\text { alto }\end{array}$ \\
\hline
\end{tabular}

The third movement „Quia fecit mihi magna” is in two parts. The first one begins with the entrance of the organ, fanfares of the timpani, and glissando of the winds; the chorus (f-ff in the high tessitura (D dur)) reflects solemn dotted rhythms of the French overture. The main motif is restated three times before being interrupted by the fanfare-like sounds. The second part „Et sanctum nomen eius” is marked „dolce and tranquillo". The main theme is a Gregorian chant from Missa "Cum Jubilo". This is the only time in the whole Magnificat where the composer incorporated a quotation.

The fourth movement „Et misericordia" starts with a calm opening theme in the orchestra. This melodious theme is first sung as a solo, then by the chorus in a unison. The fourth movement is in a form of variations A-A1-A2-A3-A4-A5-A6-A7 with a coda.

The fifth movement „Fecit potentiam” marks a culmination of the whole piece and is a rich example of intense and energetic rhythms (with elements of swing). This impetuous movement can be divided into two parts: A built on an energetic theme, and $\mathrm{B}$ - on a lyrical one that prepares the next, sixth, movement that is performed attacca.

The sixth movement, „Esurientes” opens with a peaceful orchestral theme featuring the arpeggios of a harp and is similar to that of the forth in its character, albeit is in the ternary form with the 
contrasting middle section. „Esurientes implevit bonis” is sung by a solo soprano accompanied by the orchestra with the woodwind-dominated sound. The dynamic range is held in a quieter range of $\mathrm{p}$-mf.

The final movement, „Gloria Patri" incorporates the thematic material from the I and III movements of the Magnificat replicating precisely the rhythm and corresponding structure that employs the same voice-types changing from bass to two sopranos; the only difference is that the text changes.

The musical language of the Magnificat combines different types of texture: diatonic with chromatic, homophonic with polyphonic (featuring simple and canonic imitations, the use of stretto). As a rule, the composer mostly employs the idiomatic characteristic of the Gregorian chant; only once he uses a quotation from the masse „Cum Jubilo". Combinations of freely developing melodic structures with the intense renewal of the rhythmic patterns (triplets, syncopations, polyrhythms), and the search for the new shades of timber deserve special attention.

The harmonic language of the Magnificat is highly original. It is characterised by the integration of tertian and quartal chords, dissonant harmonies, major-minor tonality, contrasting key combinations, all of which give the exuberance to the musical language of the piece.

Metre and rhythm play an important role in the Magnificat. The composer chooses alternating meters following the text, ,straightening" it up; he opts for creating contrasts concerning the texture of the piece. The composer uses mixed texture: homophonic with polyphonic (fugato, simple and canonic imitations). Throughout the piece, the density of the texture varies gradually becoming thicker at one time, thinner at the other. The themes from each movement gradually move through all parts of the chorus. The orchestra accompanying the chorus, thus playing a vital part in creating the character of the music.

Conclusions. Music of J. Rutter attracts by its openness, sincerity, lyric music images that can be easily remembered, its melodious and harmonious colours, simplicity for understanding. J. Rutter's Magnificat illustrates a new way of reading of this genre by the prime example of an unconventional embodiment of classic genre model based on the synthesis of canonical and not canonical texts (an English poem of the $\mathrm{XV}$ century). It harmoniously combines traditions and their talented renewal: in this sense, the Magnificat is a model for the musical culture 
of the second half of the XX century and the beginning of the XXI century.

The prospects of the further scientific research lie in the investigation of the Magnificat genre as a part of the creative work of modern composers and illustration of the correspondences between the different novel readings of the genre.

\section{Список використаних джерел і літератури:}

1. Раттер Джон Мілфорд Реквієм. Магніфікат: URL: http://www.loversclassic.ru/publ/skachat_audio/khorovaja/dzhon_ratter_rekviem_ magnifikat (дата звернення: 12.02.2019).

2. Раттер Джон: URL: https://en.wikipedia.org/wiki/John_Rutter (дата звернення: 17.02.2019).

3. Кучурівський Ю.С. Хорова музика сучасних британських композиторів як об'єкт музикознавчого дослідження: URL: file:///C:/Users/User/Downloads/NZTNPUm_2014_3_33.pdf

4. Уилсон-Диксон Э. История христианской музыки. Санкт-Петербург: Мирт, 2001. $428 \mathrm{c}$.

5. Wilson-Dickson A. The Story of Christian Music. Oxford: Lion Publishing, 1992. $240 \mathrm{p}$.

6. Wienandt E.A. Choral Music of the Church. New York: The Free Press, 1965. $494 \mathrm{p}$.

\section{References:}

1. Ratter Dzhon Milford, (2019). Requiem. Magnificat. Retrieved from http://www.loversclassic.ru/publ/skachat_audio/khorovaja/dzhon_ratter_rekviem_ magnifikat [in Russian].

2. Ratter Dzhon, (2019). Ratter John. Retrieved from https://en.wikipedia.org/wiki/John_Rutter[in English].

3. Kuchurivsjkyj, Ju.S. (2019). Choral music of contemporary British composers as an object of musicological research. Retrieved from file:///C:/Users/User/Downloads/NZTNPUm_2014_3_33.pdf [in Ukraine].

4. Uilson-Dikson, Je. (2001). History of Christian Music. Sankt-Peterburg: Mirt [in Russian].

5. Wilson-Dickson, A. (1992). The Story of Christian Music. Oxford: Lion Publishing [in English].

6. Wienandt, E.A. (1965). Choral Music of the Church. New York: The Free Press [in English]. 